\title{
The Role of Forced Migration in Changing the Workforce Diversity Structure and Performance Standards: The Case of Jordan
}

\author{
Mohamad Noor Al-Jedaiah ${ }^{1}$ \\ 1 Associate Professor, Faculty of Economic and Business, Business Administration Department, Jadara \\ University, Jordan \\ Correspondence: Mohamad Noor Al-Jedaiah, Associate Professor, Faculty of Economic and Business, Business \\ Administration Department, Jadara University, Jordan. E-mail: mohd_noor10@yahoo.com
}

Received: September 20, 2019

Accepted: October 25, 2019

Online Published: November 12, 2019

doi:10.5539/ijbm.v14n12p176

URL: https://doi.org/10.5539/ijbm.v14n12p176

\begin{abstract}
Migration is forming a new challenge for governmental and labor markets. The effect on workforce diversity and competiveness is considered crucial consequence of internal and external migration. The objective of this research is to investigate the effect of migration on workforce diversity in Jordan. The results showed that the external immigration to Jordan due to crisis is controlled to great extent by government. Moreover, the regulation of government of this workforce minimize its effect on local workforce market. Invisible and out of control effect resulted of local migration, which increased in the last years due to high opportunities in some governorate and the concentration of commercials in these areas. Such migration is not controlled and requires the collection of more figures, as well as deep investigation on workforce diversity.
\end{abstract}

Keywords: Migration, workforce diversity structure, performance standards

\section{Introduction}

Migration is experienced in different parts of the world. The migration effect and consequences are discussed in two directions. The first is concerned with the migration from one country to another, while the other discussed in literature considered the internal migration in a country. Different migration consequences concentrated on social and economic effects on departure and recipient places. Different authors had different attitudes for these effects. The views of effect depend on different criteria. The major criteria determine the effect on destination is the qualification of human resources received. The high experienced and educated migrants will impact positively the destination and vice versa.

Pilati et al. (2015) reported that migration would lead to high shift of the workforce composition. The change of workforce composition causes migration to be the first priority for governments due to different causes. The major represented in the high pressure on job demand in the recipient places. The other causes represented in high pressure on other sources due to the new demographic structure resulted of internal migration (Sandoval-Garcia, 2016). Moreover, Grandi (2016) reported that migration is forming a new challenge for governments and businesses. One of the effects leaved is the labor market supply and demand, besides the new commercial opportunities.

Migration in most literature discussed in two dimensions. The first dimension took into consideration the local migration, while the other dimension took into consideration the across border migration. El-Bahrawy (2016) discussed the case of migration in Egypt. The migration in Egypt was practiced in two directions. The first direction was the external migration especially to the Gulf countries, while the local migration was the other one faced in Egypt. The first migration was reported as a response to poor economic conditions and the search for other countries with more powerful economy, while the internal migration was a response of poverty and unequal distribution of opportunities. The internal injustice distribution of economic chances for different areas encouraged for internal migration.

The effect of migration on workforce and economy has been discussed as two diverse effects. The first effect was support is the positive effect on economy and the positive diversity made in workforce (Golden et al., 2018). Migrants was seen as a change force for social, economic, and workforce in different countries. This view was relying on the effect of migration on innovation, integrity and creativity of workforce. On the other hand, 
migration was seen as a force increases the competiveness in labor market leading to the selection of more skillful labor, which affect economy positively (Martin and Berstein, 2011).

Fornaro et al. (2019) reported that the effect of local migrants on diversity is higher than external migration. Birchall (2016) explained that the external migration can be controlled by the country, while the internal migration cannot be controlled as consequences, numbers and distribution. So, the internal migration cannot be controlled widely by governments and not included in policies to face any changes.

Many scholars have indicated that the increase in working population is a 'demographic bonus' or 'window of opportunity'. The question is whether Jordan will take advantage of this opportunity (Kaya, 2002; Kesaia Seniloli, 2006; Khalaf \& Al-Jedaiah, 2008).

\section{Methodology}

The objective of this paper is to investigate the effect of migration on workforce diversity structure in Jordan. To accomplish the objective of this research, secondary data produced by the Jordanian Department of Statistics, International Labor Organization and Jordanian Ministry of Labor were used. The collected data were presented and analyzed using the growth rate and the distribution of workforce according to nationalities and causes.

$$
\ln x=a+r t
$$

Where;

$\mathrm{X}$ : growth rate variable

a: constant

r: annual growth rate

t: time

The collected data represents across boarded migration and the internal migration among the governorates. The collected data cover the period 2007 to 2016. Through this period Jordan received refugees from Iraq and Syria.

\section{Results and Discussion}

\subsection{Demographic Structure, Population Growth and Migration}

The demographics structure has been changed widely in the last years due to the immigration Jordan witnessed from Iraq and Syria. Population increased dramatically. On the other hand, the drop of fertility rate and mortality rate have resulted in a change of age structure, which decreases the population in young ages $<15$ years, and increases the population in the working age group $15-64$, and the ageing people as well. This demographic explosion went in parallel with an expanded labor force, increased urbanization and rural-urban migration, and a rising gap in food self-sufficiency. For much of the period rapid population growth was of little concern to policymakers (Dhonte et al., 2000).

According to the recent population and housing census results; Jordan population increased to 9.5 million Jordanian citizens are almost 6.6 million. Jordanians consumes bread as a staple food, the same is for the 1.3 million Syrian refugees, and 636 thousands Egyptian workers resident in Jordan (DOS, 2015).

Urbanization disrupts traditional family structures and people have fewer children to rely on their in older ages. As a result, the level of savings rises as people plan for retirement that, due to health improvements, they are far more likely to reach. A high proportion of these savings tends to circulated through the economy, increasing the amount of investment available to domestic companies. This encourages modernization and can facilitate economic growth. In Jordan urbanization definition is little bit confusing so, it'll be a misleading factor. During the 100 years from 1950 to 2050, the relationship between CBRs and CDRs is characterized by four distinct phases. The Jordan data which illustrate these four stages is shown in (Figure 1). 


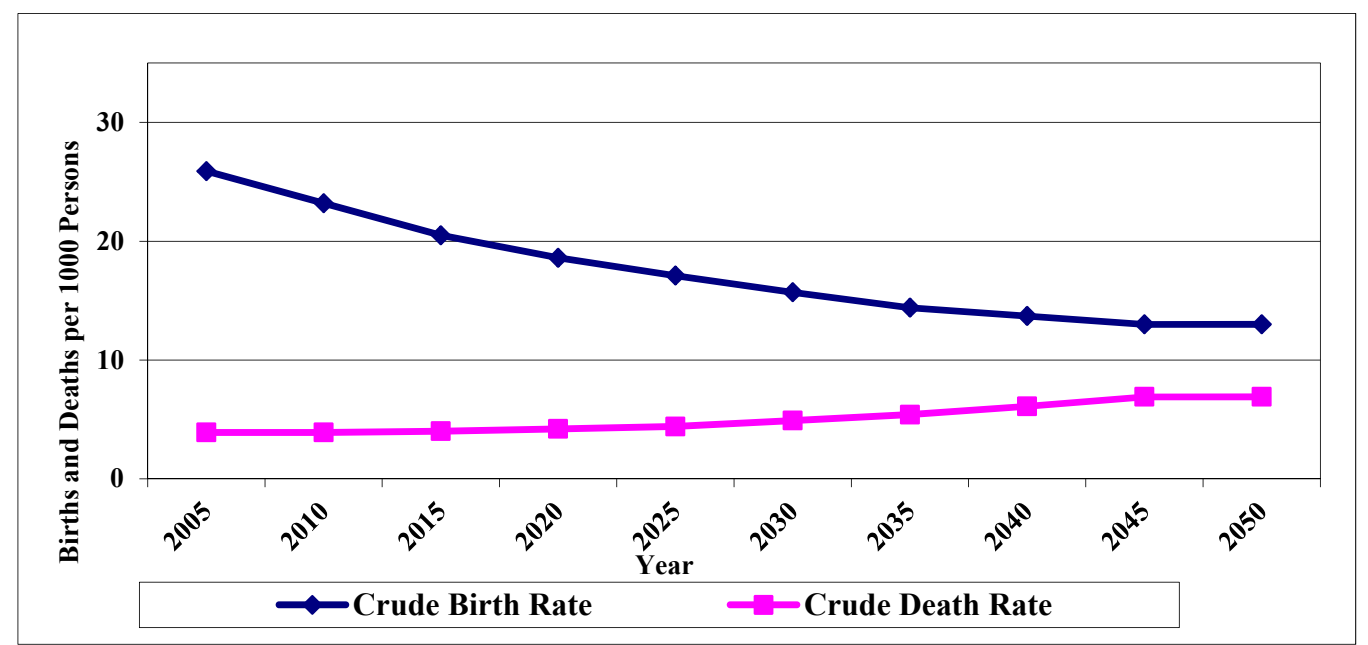

Figure 1. Crude Birth and Death Rates in Jordan (1950-2050)

Source: World Population Prospects, UN, 2019.

The first phase, from 1950 to 1970 , rates of natural increase rose rapidly because of both a rise in CBRs and a fall in CDRs. The second phase, from the 1970 tells 2000, rates of natural increase fell because of the fall in CBRs were more substantial than the fall in CDRs. The third phase, which extend from 2000 to 2030, rates of natural increase will continue to fall due to the fall in CBRs as CDRs which remains constant throughout the period. Finally, the fourth phase, will start from 2030 to 2050, rates of natural increase are expected to fall rapidly because of both a fall in CBRs and a steady relatively sharp rise in CDRs. During this latter period (and beyond), CDRs will rise in spite of an improvement in mortality levels as indicated by a rise in life expectancy (Tabbarah, 1988). Jordan have achieved the mortality transition (Goujon, et al., 2018).

Immigration has been subjected to intense checking by population economists and others; it is one of the most effective demographic parameters on population growth in Jordan despite the low fertility rates. It has played an important role in Jordan population change. This change in population structure and affected the labor force in Jordan. The last challenges that faces Jordan Government is the Iraqi big wave which have arrived to Jordan after 2004 when American have invaded Iraq so, many Iraqi people have to leave their country and big portion of them came to Jordan and till now the number is vague, but it maybe more than 100000 people. Also, the Syrian refugees received by Jordan after 2010. Figure 2 shows us the changes in population of Jordan over the years from 1952, 1961, 1979, 1994, 2004 and 2015 censuses and Estimated Population for Some Selected Years (In 000).

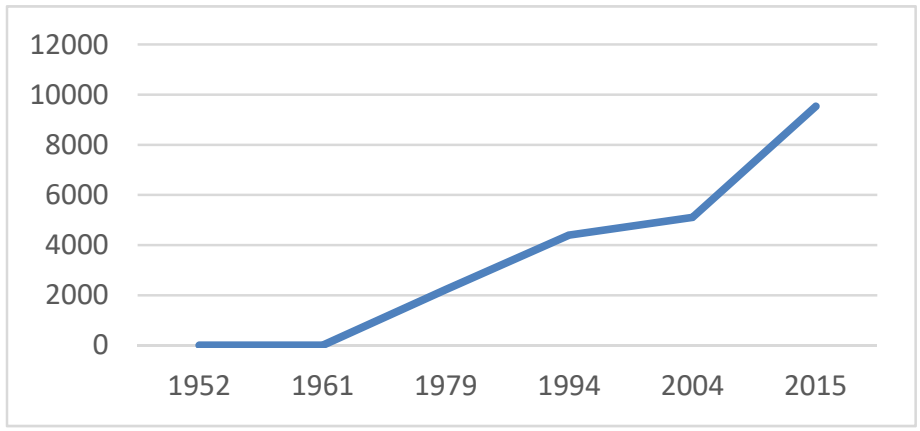

Figure 2. Population of Jordan increase, census data, and 1952 to 2015

Source: Department of Statistics, Statistical Year Book, Different Issues.

\subsection{Economic Variations and Structure}

Economic were also undergoing rapid structural transformation. Since Cairo International Conference on Population and Development in 1994, young people have been recognized as a critical target group for better health and other social policies and program (Dhonte et al., 2000). The adolescents pregnancy and childbearing 
are particular sources of social and policy concern, and many international, national, and nongovernmental organizations are now focusing more attention on the being undertaken using broad holistic approaches that incorporate elements to the situation of young people has been further reinforced in more recent years by the adoption of the United Nations Millennium Development Goals (MDG) by the international community in 2000 (Lloyd C et al., 2006).

Jordan labor market, despite the new available record of job creation which has been created in the last years, and there were a survey done by the Department of Statistics to produce data about available jobs in Jordan, this survey will be conducted annually, despite this their remain burdened by high rates of unemployment $(19.4 \%)$ for both sexes, $(18.34 \%)$ for males and $(20.13 \%)$ for females, the result of existing distortions and the legacy of the role of government as the main employer. Moreover, over the next two decades, the dynamics of demographic transition will generate great pressures as the population age structure matures.

\subsection{Local and Abroad Migration Effect on Workforce}

Jordan offers a rather unique case of a country with both extensive immigration and emigration flows. These flows have affected the growth, the distribution and the structure of the population. In 1949, the population of Jordan tripled as a result of the annexation of the West Bank. The inflow of Palestinian refugees increased the population from 400,000 to about 1.3 million persons within a single year. Between 1952 and 1961 the refugee population, which had settled mostly in the West Bank after the 1948 events in Palestine, started to move to the East Bank as a result of demographic pressure in the West Bank and more economic investments in the East Bank. Figure (3 and 4) shows the distribution of employed person in Jordan.

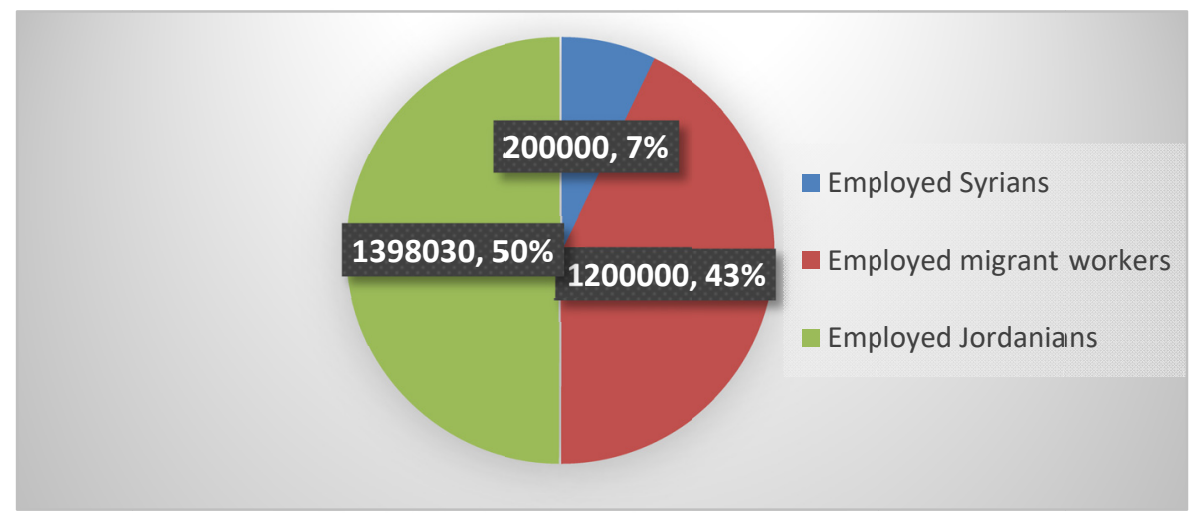

Figure 3. The distribution of employed persons in Jordan

Source: National Center for Human Resources Development and Al Manar (2016).

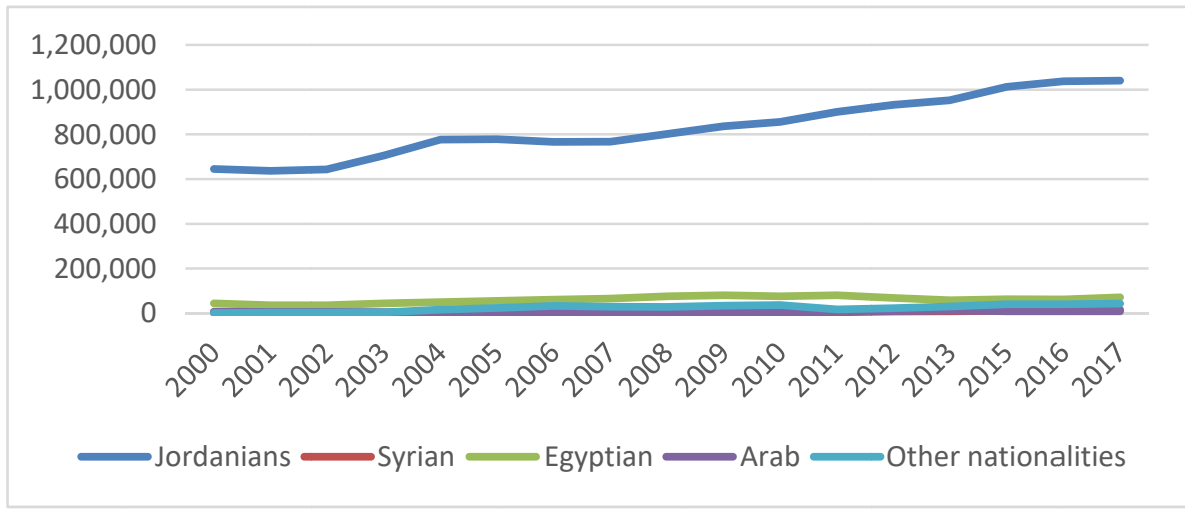

Figure 4. The distribution of employed workforce by nationality 2000 to 2017

Source: Department of Statistics, Population and Housing Census 1961, 1994 and 2004.

The migration of foreign workforce increased overtime. Table 1 shows the annual growth of Jordanian and other workforce in Jordan for the period 2000-2017. 
Table 1. Growth of workforce by nationality 2000-2017

\begin{tabular}{lllll}
\hline Workforce & Years & Growth rate & t-value & Prob. \\
\hline Jordanian & $2000-2017$ & 0.03 & 20.95 & 0.001 \\
Syrian & $2000-2017$ & 0.098 & 6.463 & 0.001 \\
Egyptian & $2000-2017$ & 0.034 & 3.87 & 0.002 \\
Arab & $2000-2017$ & 0.034 & 3.41 & 0.004 \\
Other & $2000-2017$ & 0.166 & 5.18 & 0.001 \\
\hline
\end{tabular}

Source: Department of Statistics, 2000-2017, Employment Survey, Amman, Jordan.

Jordan is not only a receiving country but it is also one of the important labor exporting countries especially to the Gulf oil-countries. The economic expansion following the jump in oil revenues which resulted from the rise of oil prices in the 1970s attracted millions of foreign workers, especially to the Arabian Peninsula. Millions have also moved from "labor-rich," non-oil producing countries to seek for jobs in the oil-rich countries within the region. The labour-importing countries especially those dependent on oil export maintained relatively high levels of temporary migration during the early 1980s, but because of the economic recession resulting from declining oil prices, have tended to reduce their intake of migrants in later years, according to this overview of migration trends, the most important changes occurring in late $80 \mathrm{~s}$ are those pertaining to labour migration towards the oil-rich countries. One aspect of international migration that generally fails to receive the attention it deserves is the extent to which women participate in international movements. Jordan had large number of labour force working in gulf oil-countries at 80s so, there were 599 (13+) returnees from Gulf in 1986 according to a self-weighted sample of 1000 household. While In 1991 immediately after the second gulf war the number of returnees was 16775 also from a self-weighted sample contains 2160 stratum, and 21920 houses, most of them were in Kuwait (Department of Statistics, 2001).

\subsection{Internal Migration Distribution}

High population growth has led to migration from smaller cities and villages to larger cities and from rural areas to urban areas. As a result, more than 78 percent of Jordan's population now live and seek their livelihood in cities (Population and Housing Census 2015). The internal migration is accompanied with the high job opportunities in large governorates as well as the high economic activities in these governorates. Table 2 shows the percentage of job creation in Jordanian governorates in the period 2007-2016. The results showed that Amman has the highest job opportunities compared to other governorates, followed by Zarqa and Irbid over the studies period. This indicates that these governorates will attract workforce from other governorates, which has higher unemployment rates specially those areas close to these governorates.

Table 2. Percentage of new job creation by governorate 2007 to 2016

\begin{tabular}{|c|c|c|c|c|c|c|c|c|c|c|}
\hline & 2007 & 2008 & 2009 & 2010 & 2011 & 2012 & 2013 & 2014 & 2015 & 2016 \\
\hline Amman & 57.6 & 54.0 & 56.6 & 53.3 & 52.9 & 45.6 & 45.3 & 47.7 & 39.1 & 47.9 \\
\hline Balqa & 3.5 & 2.3 & 5.0 & 3.0 & 3.5 & 4.9 & 5.0 & 3.4 & 1.4 & 3.6 \\
\hline Zarqa & 12.7 & 15.2 & 10.0 & 9.0 & 11.1 & 19.0 & 15.5 & 12.0 & 26.0 & 13.2 \\
\hline Madaba & 0.7 & 1.4 & 1.1 & 1.0 & 1.8 & 1.3 & 1.5 & 0.5 & 1.1 & 0.9 \\
\hline Irbid & 11.0 & 9.3 & 6.3 & 11.5 & 12.2 & 13.7 & 15.8 & 18.7 & 15.5 & 19.3 \\
\hline Mafraq & 3.6 & 5.0 & 5.2 & 4.1 & 1.7 & 2.6 & 4.6 & 4.1 & 3.6 & 4.9 \\
\hline Jerash & 2.0 & 1.3 & 2.4 & 1.8 & 2.5 & 1.6 & 1.1 & 2.6 & 1.8 & 1.2 \\
\hline Ajloun & 1.3 & 1.6 & 1.4 & 1.5 & 1.5 & 1.4 & 1.2 & 1.5 & 1.6 & 1.5 \\
\hline Karak & 1.6 & 2.2 & 4.7 & 4.7 & 6.1 & 4.6 & 3.5 & 4.6 & 2.6 & 0 \\
\hline Tafiela & 1.1 & 1.6 & 2.1 & 2.1 & 2.0 & 1.8 & 2.1 & 2.2 & 2.4 & 0.7 \\
\hline Maan & 1.8 & 2.5 & 2.8 & 3.5 & 2.3 & 1.1 & 1.8 & 2.7 & 2.0 & 3.0 \\
\hline Aqaba & 2.2 & 2.6 & 3.2 & 3.3 & 2.2 & 2.2 & 2.2 & 1.0 & 3.0 & 4.7 \\
\hline
\end{tabular}

Source: Department of Statistics, 2007-2016, Job Creation Survey, Amman, Jordan.

\subsection{Movement of Workforce among Governorates}

Internal workforce migration is a common phenomenon in Jordan. The structure of social structure as well as the close distance between the northern and middle governorates facilitates the workforce movement. Table 3 
explains the movement of workforce received by each governorate as a percentage of total workforce. The results show that the governorates receive the highest workforce are the located in the middle area, while the least existed in the north area. This resulted of the high commercial activities in the middle governorates compared to northern and southern governorates in Jordan.

The structure of population of governorates explains the movement among governorates. According to the Department of Statistics, Amman governorate has the largest percentage of Jordan population, while Balqa governorate has the fourth large percent of the population, whilst Zarqa comes in the second place. On the other hand, Mafraq, Jarash, Ajlun, Tafeila \& Aqaba were have the lowest percent of the population.

Key forces shaping the future of Jordan cities include population growth and migration, the role of the urban economy, and provision of urban services and housing. It also adds more problem of water scarcity, which is already, is serious. Jobs are not being created fast enough to absorb the growing number of workforce.

Table 3. The percentage of workforce received by governorate 2011 to 2016

\begin{tabular}{lllllll}
\hline & $\mathbf{2 0 1 1}$ & $\mathbf{2 0 1 2}$ & $\mathbf{2 0 1 3}$ & $\mathbf{2 0 1 4}$ & $\mathbf{2 0 1 5}$ & $\mathbf{2 0 1 6}$ \\
\hline Amman & 28.7 & 32.2 & 20.5 & 31.1 & 42.0 & 21.7 \\
Balqa & 51.9 & 38.5 & 10.4 & 24.5 & 58.0 & 27.3 \\
Zarqa & 38.5 & 52.6 & 49.3 & 61.9 & 67.6 & 42.6 \\
Madaba & 24.5 & 00 & 5.4 & 45.9 & 3.7 & 4.8 \\
Irbid & 3.5 & 5.5 & 3.6 & 9.0 & 0.6 & 4.9 \\
Mafraq & 0.8 & 00 & 10.5 & 34.4 & 29.9 & 7.5 \\
Jerash & 17.3 & 19.6 & 12.6 & 26.9 & 12.5 & 26.6 \\
Ajloun & 1.9 & 16.1 & 10.4 & 4.8 & 4.6 & 0.8 \\
Karak & 25.2 & 2.6 & 2.2 & 15.0 & 18.2 & -- \\
Tafiela & 34.9 & 41.6 & 23.4 & 54.3 & 36.0 & 53.8 \\
Maan & 22.4 & 30.2 & 28.1 & 25.7 & 20.7 & 25.8 \\
Aqaba & 36.9 & 33.3 & 16.0 & 100 & 28.7 & 16.5 \\
\hline
\end{tabular}

Source: Department of Statistics, 2011-2016, Job Creation Survey, Amman, Jordan.

\section{Conclusion}

The objective of this research was to investigate the effect of migration on workforce in Jordan. The secondary data was used to reach this objective. Department of Statistics was the major source to provide this data. The results showed that migration of workforce occurs internally and externally. The data showed that the Egyptian and Syrian workforce were the highest compared with other workforces. In the last years, the competiveness of Syrian workforce on jobs was higher and affected the Jordanian labor market. The external migration was found to compete local workforce for jobs in specific sectors.

The local migration was witnessed from low population governorates to high population governorates due to high job opportunities and high economic activities in these governorates. The distance between governorates was the determinant of internal workforce movement in Jordan. The governmental policies should be directed to create job opportunities within each governorate to minimize the pressure on job in large governorates.

\section{References}

Aljawarneh, N. M. S., \& Atan, T. (2018). Linking Tolerance to Workplace Incivility, Service Innovative, Knowledge Hiding, and Job Search Behavior: The Mediating Role of Employee Cynicism. Negotiation and Conflict Management Research, 11(4), 298-320.

Birchall, J. (2016). Gender, age and migration: An extended briefing. IDS.

Department of Statistics. (2005-2017). Workforce Market Survey. Amman, Jordan.

Dhonte, M. P. (2000). Demographic transition in the middle east-implications for growth, employment, and housing. International Monetary Fund.

El-Bahrawy, A. (2016). Migration in Egypt: Socioeconomic Dimensions. Exceed Conference, Berlin, Germany.

Fornaro, P., Maliranta, M., \& Rouvinen, P. (2019). Immigrant Innovators and Firm Performance (No. 63). ETLA Working Papers. 
Golden, I., Pitt, A., Nabarro, B., \& Boyle, K. (2018). Migration and the economy. Oxford University Press.

Grandi, F. (2016). Managing the refugee and migrant crisis: The role of governments, private sector and technology. Global Crisis Center, PWC.

Kaya, B. (2002). The Changing Face of Europe: Population flows in the 20th century. Council of Europe.

Khalaf, S. A. J., \& Al-Jedaiah, M. N. (2008). Software quality and assurance in waterfall model and XP: a comparative study. WSEAS Transactions on Computers, 7(12), 1968-1976.

Lutz, W., Goujon, A., KC, S., Stonawski, M., \& Stilianakis, N. (2018). Demographic and Human Capital Scenarios for the 21st Century: 2018 assessment for 201 countries. Publications Office of the European Union.

Martin, S., \& Berstein, H. (2011). Migration: Ensuring access, dignity, respect of diversity and social inclusion. International Federation of Red Cross and Red Crescent Societies.

National Center for Human Resources Development and Al Manar. (2016). Employment Database. Retrieved from http://www.almanar.jo/en/human-resources-information/hristatistics

Pilati, M., Sheikh, H., Sperotti, F., \& Tilly, C. (2015). Introduction: Understanding the Causes, Consequences and possible response to Global Migration Flow. In How Global Migration Changes the Workforce Diversity Equation. Cambridge Scholars Publishing. UK.

Ratha, D., Mohapatra, S., \& Scheja, E. (2016). Impact of migration on economic and social development: A review of evidence and emerging issues. World Bank Policy Research, Working Paper No. 5558.

Razzaz, S. (2017). A Challenging Market Becomes More Challenging: Jordanian Workers, Migrant Workers and Refugees in the Jordanian Labour Market. Retrieved from http://www.ilo.org/wcmsp5/groups/public/---arabstates/---ro-beirut/documents/publication/wcms_556931.p df

Sandoval-Garcia, C. (2016). Central American Forced Migration: Expelled Population and policy containment. Exceed Conference, Berlin, Germany.

Seniloli, K. L. (2006). To Take Advantage of the Demographic Window of Opportunity or Not. That Is the Question: The Case of Fiji. In Age Structural Transitions Challenges for Development. CICRED, 133, Bd Davout.

Tabbarah, R. (1988). Challenges in Arab demography. Popul Bull ESCWA, 33, 3-16.

United Nations. (2019). World Population Prospects. New York.

\section{Copyrights}

Copyright for this article is retained by the author(s), with first publication rights granted to the journal.

This is an open-access article distributed under the terms and conditions of the Creative Commons Attribution license (http://creativecommons.org/licenses/by/4.0/). 